\title{
SISTEM INFORMASI BADAN PENGURUS DAERAH KERUKUNAN KELUARGA SULAWESI SELATAN (BPD-KKSS) KAB. INHIL
}

\author{
Syahreni ${ }^{1}$, samsidin $^{2}$, Ilyas $^{3}$ \\ ${ }^{1}$ Program Studi Sistem Informasi, Fakultas Teknik dan Ilmu Komputer, Universitas Islam Indragiri, \\ Tembilahan \\ Email: samsudinsadek@gmail.com (korespondensi)
}

\begin{abstract}
Until now, the South Sulawesi Family Harmony Organization, Indragiri Hilir Regency does not yet have a special application that helps administrators in managing the administration of member data collection, the South Sulawesi Family Harmony Organization is a family social organization that gathers its members overseas. The purpose of the benefits of this research is to assist administrators in managing administration in the form of providing information system media as a tool in managing member data. This BPD-KKSS Kab.Inhil Information System was created using the PHP programming language and CodeIgniter Framework, using MySQL as a database, the Waterfall method as the software development method used, PIECES analysis as the analysis used in this training and using UML design in managing the proposed design. created and using the Alpha and beta methods for testing. With this registration information system, it is hoped that it can help the management in collecting member data, making it easier to find member information if needed at any time
\end{abstract}

Keywords: Web Information System, Resistration Information System ,KKSS

\begin{abstract}
Abstrak
Sampai saat ini, Organisasi Kerukunan Keluarga Sulawesi Selatan Kabupaten Indragiri Hilir belum memiliki aplikasi khusus yang membantu pengurus dalam mengelola administrasi pendataan anggota, Organisasi Kerukukan Keluarga Sulawesi Selatan merupkan organisasi sosial kemasyarakatan yang bersifat kekeluargaan menghimpun anggotanya ditempat perantauan. Tujuan dari manfaat penelitian ini membantu pengurus dalam mengelola administrasi dalam bentuk menyediakan media sistem informasi sebagai alat bantu dalam mengelola data anggota. Sistem Informasi BPD-KKSS Kab.Inhil ini dibuat mengunakan bahasa pemrograman PHP dan Framework CodeIgniter, menggunakan MySQL sebagai database, metode Waterfall sebagai metode pengembangan perangkat lunak yang digunakan, analisa PIECES sebagai analisa yang digunakan dalam peletian ini dan menggunakan perancangan UML dalam mengelola rancangan usulan yang dibuat serta mengunakan metode Alpha dan beta untuk pengujian. Dengan adanya sistem informasi pendaftaran ini diharapkan dapat membantu pengurus dalam pendataan anggota memudahkan dalam pencaraian informasi anggota jika sewaktu-waktu diperlukan.
\end{abstract}

Kata kunci: Sistem Informasi Berbasis Web, Sistem Informasi Pendaftaran, KKSS

\section{Pendahuluan}

Perkembangan aplikasi saat ini sangatlah pesat untuk menunjang kinerja, salah satu aplikasi yang sering digunakan adalah aplikasi berbasis website dalam memberikan informasi yang cepat dan akurat. Mulai dari perusahaan-perusahaan, sekolah-sekolah, lembaga-lembaga pemerintahan, perguruan tinggi, organisasi-organisasi maupun dinasdinas biasanya menggunakan aplikasi berbasis web untuk mempermudah memberikan informasi. Serta pemakaian media Komputer dan Smartphone pada Lembaga, Instansi, Organisasi ataupun Masyarakat sudah dilakukan dengan baik (Priyadi \& Lestari, 2018) dalam [1]. Salah satu bentuk dari teknologi informasi yang dapat mendukung aktifitas bisnis dan menciptakan keunggulan bagi sebuah Organisasi adalah sistem informasi. 
Informasi adalah fakta yang diolah menjadi bentuk yang lebih berguna dan lebih berarti bagi yang menerimanya [2]. Jadi sistem informasi yang didalam Organisasi mempertemukan kebutuhan pengolahan transaksi harian, mendukung operasi yang bersifat manajerial yang menyediakan pihak luar dapat mengakses laporan laporan tertentu yang digunakan.

Dimana sistem informasi ini dapat menyimpan data dengan aman dan tidak membutuhkan ruang yang besar untuk media penyimpanan datanya. Organisasi yang sudah menerapkan sistem informasi pada bidang tertentu dan menggunakannya secara efektif, akan sangat mudah dalam hal melakukan pengolahan data berbeda dengan organisasi yang belum menggunakan sistem informasi karena pada umumnya akan mengalami kesulitan dalam pengelolaan data serta pengelolaan informasi. Salah satu Organisasi di Indragiri Hilir yang belum menerapkan sistem informasi dalam hal merapikan administrasi atau pengelolaan data adalah Organisasi KKSS (Kerukunan Keluarga Sulawesi Selatan).Organisasi KKSS ini sendiri merupakan Organisasi Masyarakat Suku Bugis yang bergerak dibidang kemasyarakatan bersifat kekeluargaan menghimpun anggotanya ditempat perantauan yang di amanahkan dalam Konstitusi Negara kita UUD 1945 dan dijabarkan dalam UU Nomor 17 tahun 2013 tentang Organisasi Kemasyarakatan (Ormas) [3].

Dalam Organisasi KKSS Kab.Inhil ini belum adanya sistem informasi yang digunakan untuk merapikan administrasi. Sedangkan penerimaan anggota oleh Organisasi KKSS INHIL yang semakin meningkat setiap harinya, membuat pengurus dari Organisasi KKSS ini kesulitan dalam mengelola data anggota, dikarenakan hanya mengikuti Grup dari Fanpage sosial media seperti Grup Facebook dan WhatsApp. Oleh karena itu penulis mencoba membuat suatu aplikasi sistem informasi berbasis Website yang dapat menggantikan hal tersebut terjadi.

\section{TINJAUAN PUSTAKA}

Penelitian mengenai pendaftaran anggota baru sudah banyak dilakukan, seperti Lestari
\& Mirchandini 2019 [1] dalam penelitiannya yang berjudul Sistem Informasi Pendaftaran Anggota Baru Pada Palang Merah Indonesia (PMI) Jakarta berfokus pada pengolahan data organisasi yang dibutuhkan dalam organisasi, aplikasi yang mereka kelola mempersempit kemungkinan dalam menghilangkan data peserta anggota baru, dan data-data yang penting. Sehingga seluruh aspek dalam organisasi dikelola dalam aplikasi yang dikembangkan ini, penelitian ini mengaju pada metode penelitian menggunakan perancangan Waterfall dimana perancangan juga meliputi pembuatan desain aplikasi menggunakan Data Flow Diagram (DFD) dan Entity Relationship Diagram (ERD). Pada penelitian Jannah 2019 [4] yang berjudul Perancangan Sistem Informasi Pendaftaran Organisasi Unit Kegiatan Khusus Berbasis Web di Iain Bukittinggi berdasarkan hasil penelitian yang dilakukan, disini peneliti menggunakan model pengembangan sistem yang digunakan adalah waterfall yang terdidi dari 5, yaitu : (1) perencanaan penelitian, (2) requirement analysis, (3) software design and modeling, (4) software development, dan (5) software testing.

Penelitian yang dilakukan oleh Ramadon 2018 [5] Perancangan Sistem Informasi Pendaftaran Ekstrakurikuler Berbasis Web Pada Smk Malaka Jakarta dan Sarwindah 2018 [6] Sistem Pendaftaran Siswa Baru Pada Smp N 1 Kelapa Berbasis Web. Menggunakan metode pengembangan Waterfall dan metode SDLC serta UML dalam penelitiannya membangun sistem informasi administrasi Kegiatan Ekstrakulikuler siswa yang dapat menjadi penguhubung komunikasi antara organisasi dengan admin bagian Kesiswaan, sistem yang dibangun juga menghasilkan laporan kegiatan, laporan proposal kegiatan dan laporan pelaksanaan kegiatan.

Penelitian terdahulu menggunakan bahasa pemrograman HTML, PHP, CSS, dan Java Script, sedangkan yang sekarang bahasa pemrograman yang digunakan adalah PHP dan MySQL. Pada penelitian terdahulu metode yang digunakan adalah metode waterfall, sedangkan yang sekarang menggunakan metode pieces. Kemudian perancangan menggunakan ERD (Entity 
Relatonship Diagram) dan DFD (Data Flow Diagram), sedangkan yang sekarang menggunakan usecase diagram, squene diagram, activity diagram dan class diagram. Penelitian terdahulu menggunakan pengujian black box testing, sedangkan penelitian sekarang menggunakan pengujian Alhpa dan white Beta.

\section{METOdOLOGI PENELITIAN}

Penelitian ini dilakukan dengan berbagai langka kerja yang sistematis sehingga mendapat hasil yang optimal langka kerja penelitian merupakan serangkaian prosedur dan langka-langka dalam melakukan penelitian yang tersetruktur secara sistematis dan terarah agar tujuan dari penelitian ini bisa tercapai dengan baik. Pada Alur Penelitian ini penulis menggunakan Metode Waterfall dapat dilihat pada Gambar 1 Berikut ini.

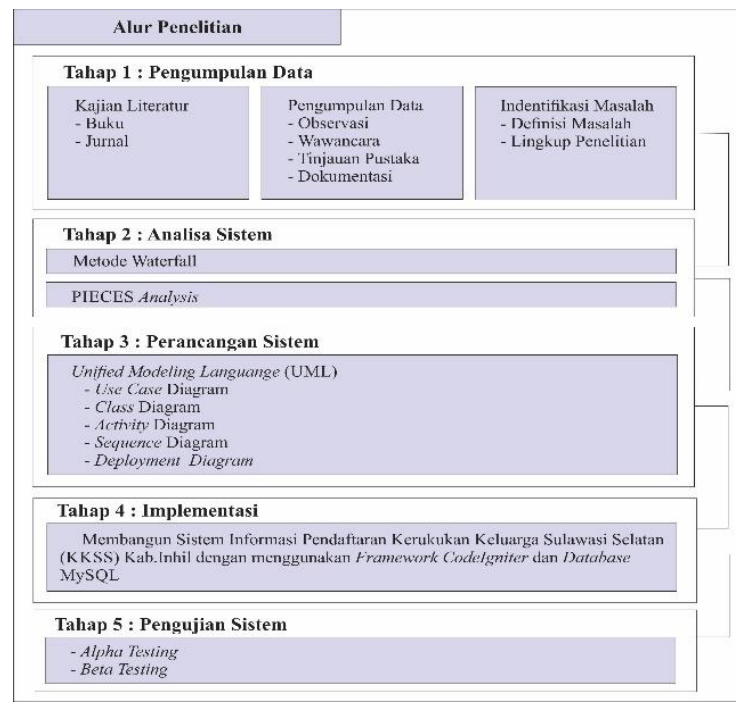

Gambar 1. Bagan Alur Metode Penelitian

\section{Pengumpulan data}

Pengumpulan data yang dilakukan ialah wawancara, observasi dan juga melakukan studi literatur. Pada penelitian ini dilakukan pengamatan secara langsung Di Sekretariat KKSS dan wawancara yang dilakukan tatap muka beserta tanya jawab langsung antara peneliti dan Ketua Badan Pengurus Daerah Bpk H. Abdullah Mandu, S.Pd.I., MM dan Bpk Abdul Aziz, S.Ag selaku Wakil Sekretaris Badan Pengurus Daerah Kab.Inhil, dan pada tahap studi literatur, peneliti mencari sumber-sumber tulisan berupa jurnal ataupun buku yang berhubungan dengan penelitian dan berhubungan dengan perancangan program yang digunakan sebagai referensi pada penelitian yang sedang dilakukan.

\section{Analisa Sistem}

Menurut Hanif Al Fattah dalam [7] Metode PIECES ialah metode analisis selaku dasar untuk mendapatkan pokok- pokok permasalahan yang lebih spesifik. Analisis ini disebut analisis PIECES (Performance, Information, Economic, Control, Efficiency and Service).

\section{Perancangan Sistem}

Perancangan sistem penulis menggunakan Unified Modeling Language (UML) menurut Windu Gata \& Grace dalam [8] UML adalah bahasa spesifikasi standar yang dipergunakan untuk mendokumentasikan, menspesifikasikan dan membanngun perangkat lunak. UML merupakan metodologi dalam mengembangkan sistem berorientasi objek dan juga merupakan alat untuk mendukung pengembangan sistem.

\section{Implementasi}

Implementasi adalah suatu kebijakan dalam penyelesaian keputusan demi tercapainya tujuan yang baik dengan bergantung bagaimana implementasi yang berjalan dengan baik dalam melaksanakan proses penyempurnaan akhir.

\section{Pengujian Sistem}

Pengujian sistem berisi tentang pengujian fungsional sistem (Mohd \& Shahbodin, 2015) dalam [9]. Pengujian dilakukan dengan 2 pendekatan alpha testing dan beta testing. Alpha testing dilakukan untuk menguji fungsioanal sistem menggunakan metode Black box testing, sedangkan beta testing dilakukan kepada pengguna atau User Acceptance Testing menggunakan kuesioner.

\section{HASIL DAN PEMBAHASAN}

\section{Analisa Sistem}

Analisa sistem sebagaimana pada tabel berikut, 
Tabel Error! No text of specified style in document..1 Analisis PIECES Sistem Informasi

\begin{tabular}{|c|c|c|c|}
\hline No & $\begin{array}{l}\text { Analisis } \\
\text { Masalah }\end{array}$ & Sistem Lama & Sistem Baru \\
\hline 1. & Performance & $\begin{array}{l}\text { Waktu yang } \\
\text { diperlukan } \\
\text { untuk mencari } \\
\text { data anggota } \\
\text { membutuhkan } \\
\text { waktu yang } \\
\text { lama }\end{array}$ & $\begin{array}{l}\text { Dapat } \\
\text { mempersingkat } \\
\text { waktu dan } \\
\text { mempermudah } \\
\text { proses } \\
\text { pencarian data } \\
\text { yang tersi- } \\
\text { mpan secara } \\
\text { otomatis di } \\
\text { database. }\end{array}$ \\
\hline 2. & Information & $\begin{array}{l}\text { Informasi data } \\
\text { diri anggota } \\
\text { hanya dapat } \\
\text { diperoleh jika } \\
\text { pengurus } \\
\text { menghubungi } \\
\text { langgusung } \\
\text { pihak anggota } \\
\text { Organisasi } \\
\text { secari pribadi } \\
\text { melalui } \\
\text { WhatsApp. }\end{array}$ & $\begin{array}{l}\text { Informasi data } \\
\text { diri anggota } \\
\text { dapat } \\
\text { diperoleh } \\
\text { secara online } \\
\text { tanpa harus } \\
\text { menghub-ungi } \\
\text { pihak anggota. }\end{array}$ \\
\hline 3. & Economy & $\begin{array}{l}\text { Dalam proses } \\
\text { pengum-pulan } \\
\text { berkas atau } \\
\text { data, masih } \\
\text { dalam bentuk } \\
\text { cetak sehingga } \\
\text { membutuhkan } \\
\text { tempat untuk } \\
\text { penyimpanan } \\
\text { arsip }\end{array}$ & $\begin{array}{l}\text { Dalam proses } \\
\text { pengumpulan } \\
\text { berkas atau } \\
\text { persyaratan } \\
\text { dalam bentuk } \\
\text { Softfile akan } \\
\text { tersimpan } \\
\text { pada database }\end{array}$ \\
\hline 4. & Control & $\begin{array}{l}\text { Pendataan } \\
\text { secara manual } \\
\text { akan mudah } \\
\text { terjadi } \\
\text { kesalahan dan } \\
\text { harus mencari } \\
\text { satu persatu } \\
\text { untuk } \\
\text { memperbaikinya }\end{array}$ & $\begin{array}{l}\text { Karna sudah } \\
\text { tersistem, } \\
\text { kesalahan } \\
\text { dalam } \\
\text { pendataan } \\
\text { dapat } \\
\text { diminimalisir, } \\
\text { dapat dicari } \\
\text { dan dapat } \\
\text { diperbaha-rui } \\
\text { dengan cepat. }\end{array}$ \\
\hline
\end{tabular}

\section{Hasil Desain}

Dalam perancangan sistem pada penelitian ini digunakan pemodelan dengan pendekatan UML (Unified Modeling Language), adapun diagram yang akan digunakan untuk pemodelan perancangan proses untuk sistem ini akan dijelakan dibawah ini.

A. Use Case Diagram

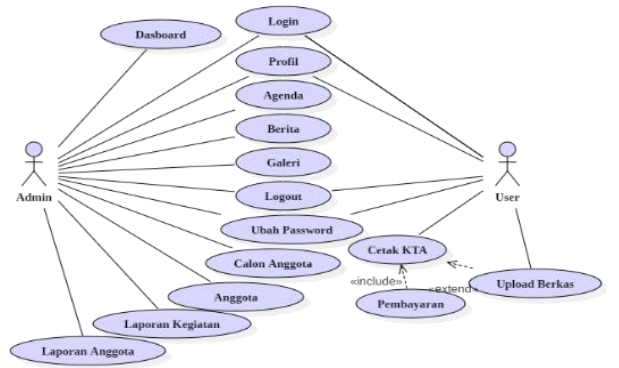

Gambar 2. Use case Diagram Utama

Pada Gambar 2 diatas terdapat 2 aktor yang mempunyai hak akses dalam diagram use case yang berinteraki dengan sistem yaitu: Dimana admin dapat mengakses login, profil, agenda,berita, galery, aprove calon anggota, laporan kegiatan, laporan anggota, mengubah password, serta logout. Sedangkan anggota hanya dapat melihat, agenda, berita, dan mengakses login, profil saya upload berkas, cetak KTA ubah password, dan logout.

\section{B. Activity Diagram}

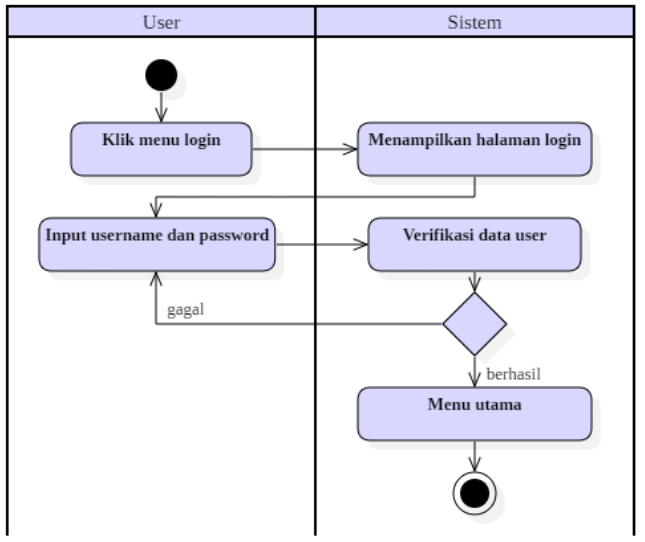

Gambar 3. Activity Diagram Login User

Pada Gambar 3 diatas menjelaskan tentang alur proses login dari user dimulai dari membuka webite terlebih dahulu lalu klik menu login pada website kemudian sistem menempilkan form login dan user memasukkan username dan password, kemudian sistem melakukan validasi, jika berhasil maka lanjut ke menu utama jika gagal maka kembali mengisi username dan password yang benar. 


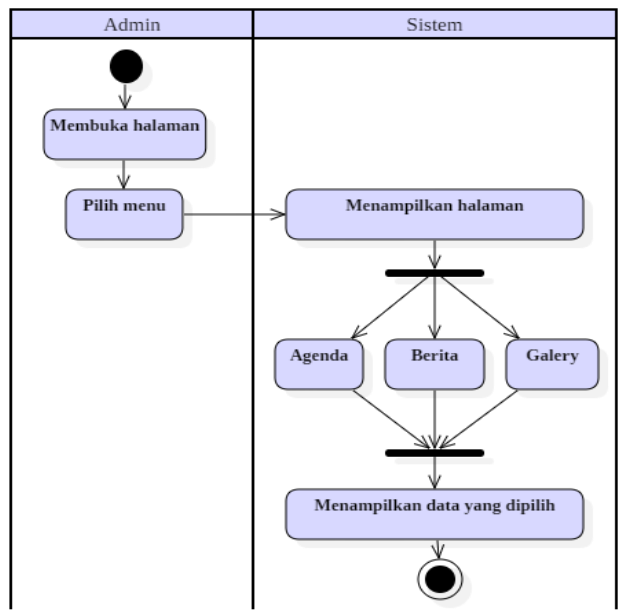

Gambar Error! No text of specified style in document.. Activity Diagram Input data

Pada Gambar 4 diatas menjelaskan tentang bagaimana admin melakukan penginputan data seperti agenda dan berita, dimulai dari membuka website, admin memilih menu agenda, berita atau galery, kemudian sistem menampilkan input, kemudian admin mengenginput data, setelah itu data ditampilkan.

\section{Squence Diagram}

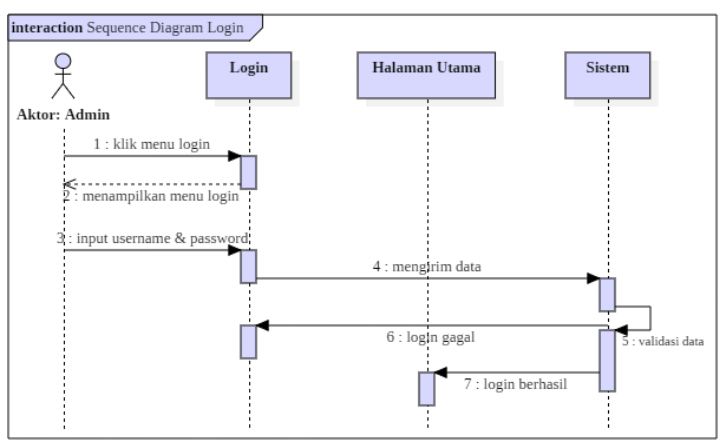

Gambar 5. Squence Diagram Login User

Pada Gambar 5 diatas merupakam Squence Diagram Login Proses dimulai pada saat user membuka halaman login maka akan menampilkan tampilan masuk. Ialu admin akan memasukkan username dan password serta mengisi halaman login. Setelah itu dilakukan validasi data dan jika data benar maka akan menampilkan halaman utama website.

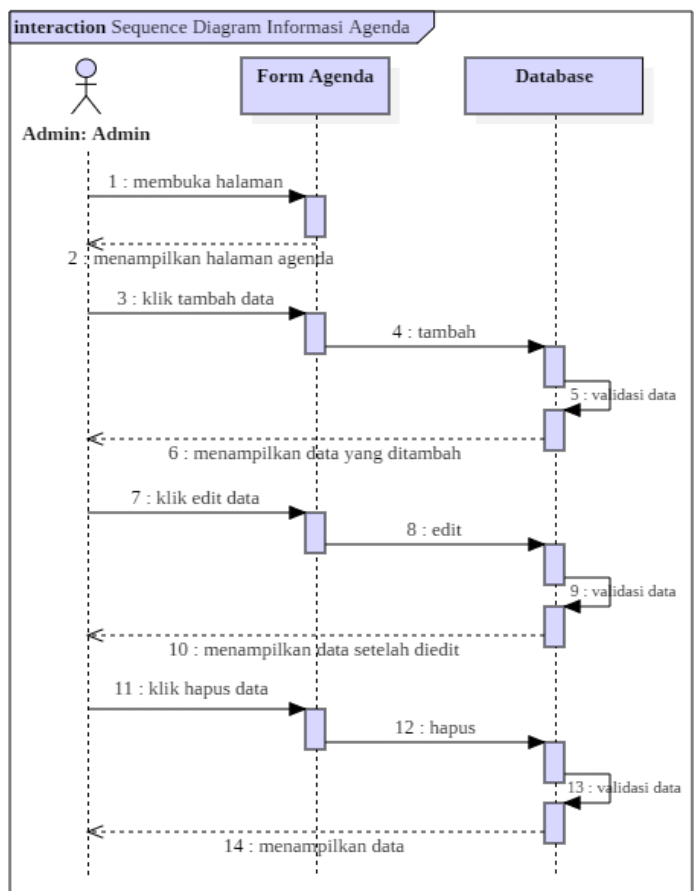

Gambar 6. Squence Diagram Input Agenda

Dari gambar 6 sequence diagram agenda dapat dilihat bahwa admin dapat mengelola data informasi dengan aksi yang dapat dilakukan yaitu menambahkan data, mengedit data dan menghapus data informasi yang ada.

D. Class Diagram

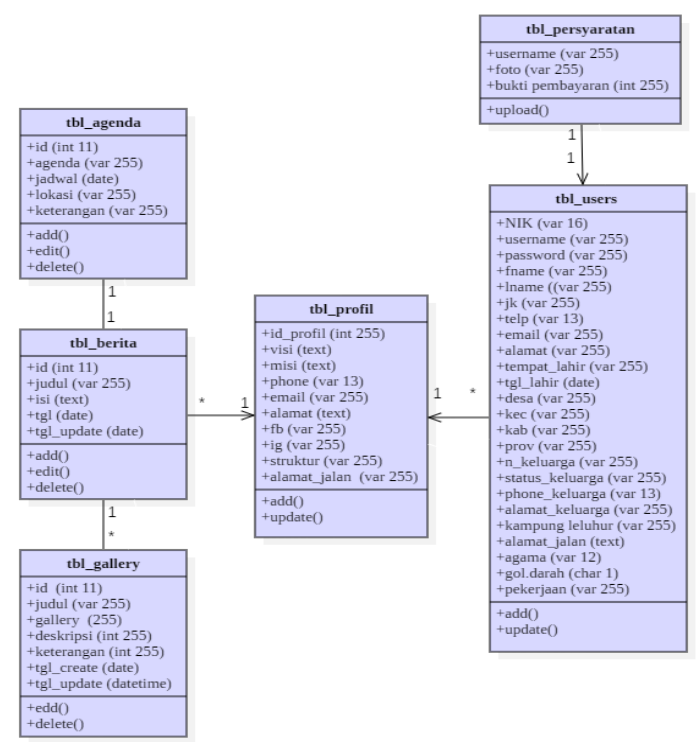

Gambar 7. Class Diagram

Class diagram diatas pada Gambar 7 adalah diagram yang digunakan untuk menampilkan beberapa pada sistem informasi BPD-KKSS Kab.inhil, Class diagram menunjukkan hubungan antar class dalam 
sistem yang sedang dibangun dan bagaimana mereka saling berkolaborasi untuk mencapai suatu tujuan yang memiliki database sebagai tempat penyimpanan data yaitu, tabel user, tabel profil (admin), tabel persyaratan, tabel agende, tabel berita dan tabel galery.

\section{Implementasi Sistem}

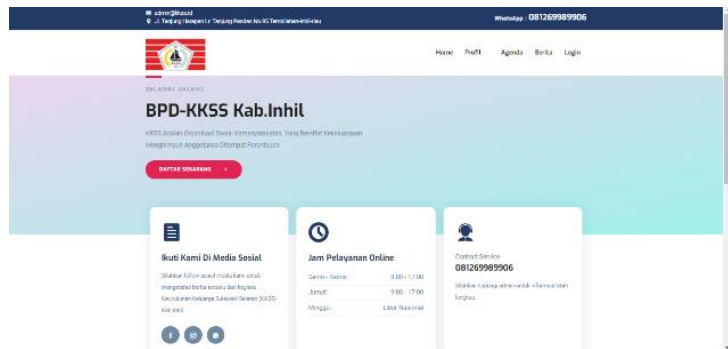

Gambar 8. Halaman Website

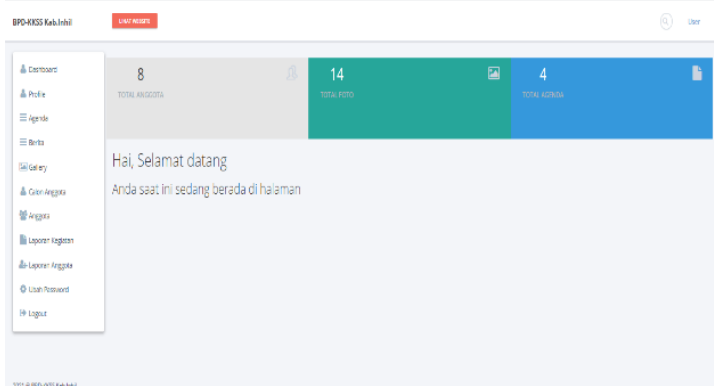

Gambar 9. Halaman Dasboard Admin

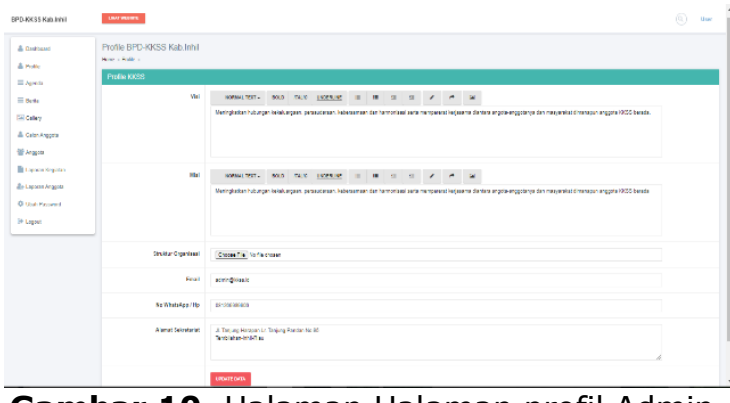

Gambar 10. Halaman Halaman profil Admin

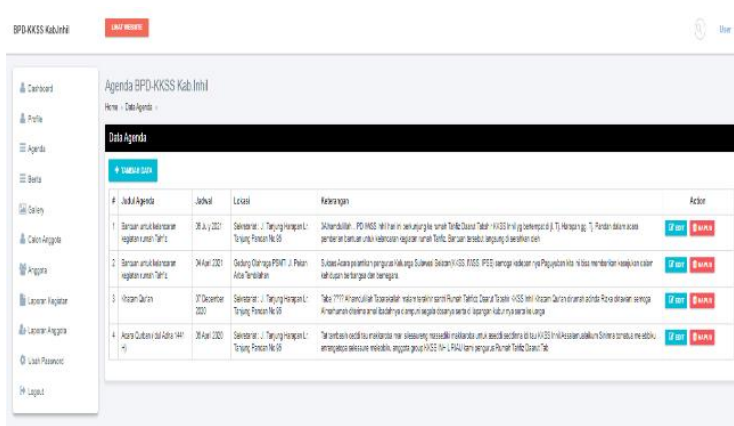

Gambar 11. Halaman Agenda

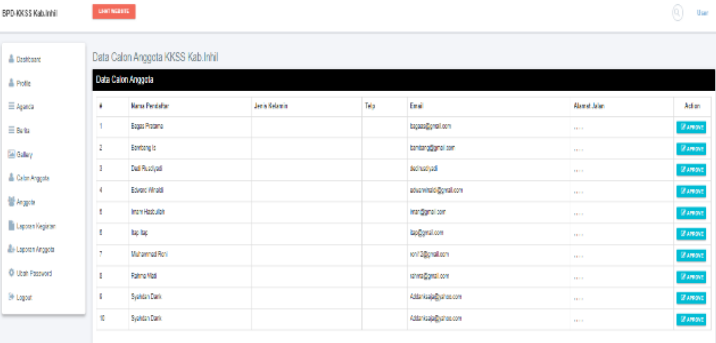

Gambar 12. Halaman Calon Anggota

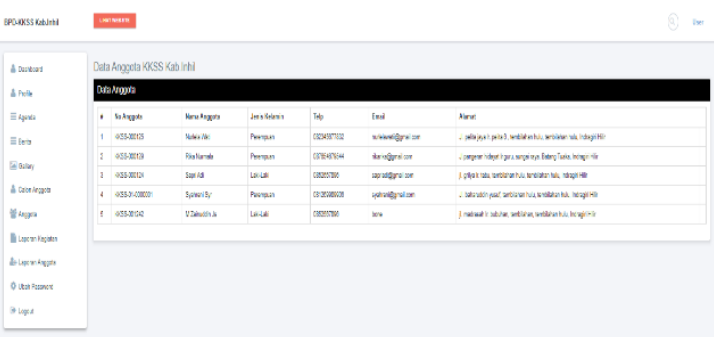

Gambar 13. Halaman View Anggota

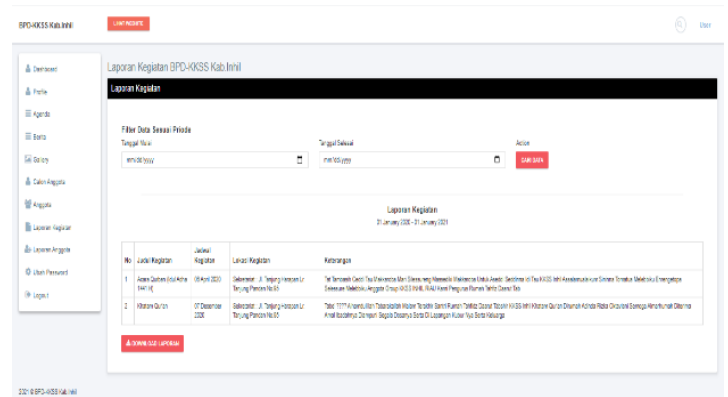

Gambar 14. Halaman Laporan Kegiatan

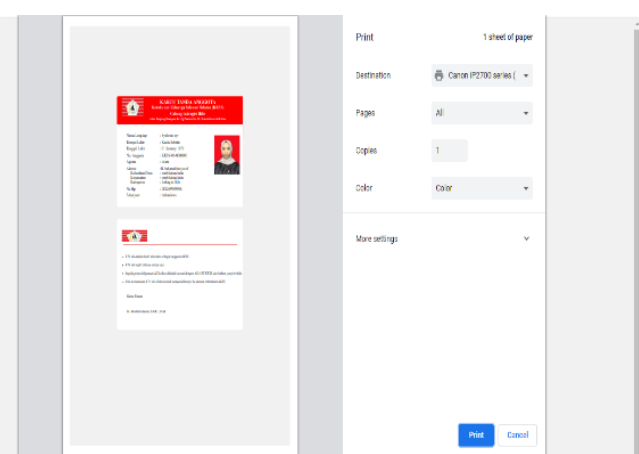

Gambar 15. Halaman Cetak KTA

\section{KESIMPULAN DAN SARAN}

Sistem Informasi BPD-KKSS Kab.Inhil ini dibuat mengunakan bahasa pemrograman PHP dan Framework CodeIgniter, menggunakan MySQL sebagai database, metode Waterfall sebagai metode pengembangan perangkat lunak yang digunakan, analisa PIECES sebagai analisa yang didgunakan dalam peletian ini dan menggunakan perancangan UML dalam mengelola rancangan usulan yang dibuat 
serta mengunakan metode Alpha dan beta untuk pengujian. Dengan adanya sistem informasi pendaftaran ini membantu sistem informasi Kerukunan Keluarga Sulewesi Selatan(KKS) dalam pengolahan data dan Informasi yang dibutuhkan dalam pengambilan keputusan.

\section{UCAPAN TERIMA KASIH}

Terimakasih kepada Organisasi KKSS yang telah memberikan data dan informasi serta memberikan kesempatan untuk observasi dan wawancara.

\section{DAFTAR PUSTAKA}

[1]. E. W. Lestari and N. Y. Mirchandini, "Sistem Informasi Pendaftaran Anggota Baru Pada Palang Merah Indonesia ( PMI ) Jakarta," J. Komput. dan Inform. Univ. Bina sarana Inform., vol. XXI, no. 2, pp. 173-178, 2019.

[2]. F. Yunita, "Analisa Dan Perancangan Sistem Informasi Izin Usaha Jasa Konstruksi," J. Sistemasi, vol. 6, no. September, pp. 52-59, 2017.

[3]. "Kkss-inhil." Riaulink.com, Tembilahan, 2021.

[4]. M. Jannah, "Perancangan Sistem Informasi Pendaftaran Organisasi Unit Kegiatan Khusus Berbasis Web di IAIN Bukittinggi," J. Informormatika, vol. 6, no. 2, pp. 185-192, 2019.

[5]. A. S. Ramadon, "Perancangan Sistem Informasi Pendaftaran Ekstrakurikuler Berbasis Web Pada SMK Malaka Jakarta," J. Komput. dan Inform. Akad. Bina Sarana Inform., vol. XX, no. 2, 2018.

[6]. Sarwindah, "Sistem Pendaftaran Siswa Baru Pada SMP N 1 Kelapa Berbasis Web," J. Sisfokom, vol. 07, no. September, pp. 110-115, 2018.

[7]. A. R. Dewi, "Analisis Sistem Informasi Pengolahan Data Nilai Mahasiswa Menggunakan PIECES pada Prodi Sistem Informasi,"J.Sistem Informasi, vol. 5341, no. October, pp. 37-46, 2018.

[8]. A. Hendini, "Pemodelan UML Sistem Informasi Monito," J. Khatulistiwa Informatika, vol. IV, no. 2, pp. 107116, 2016.

[9]. R. Wahyudi and K. Rhinaldi, "Aplikasi pembayaran administrasi santri terintegrasi SMS gateway," Regist. J. IIm. Teknol. Sist. Inf., vol. 4, no. 1, pp. 91-102, 2018. 